\title{
Knowledge Work: Gender-Blind or Gender-Biased?
}

Truss, C., Conway, E., D'Amato, A., Kelly, G., Monks, K., Hannon, E. and Flood, P. (2012) 


\begin{abstract}
Knowledge-intensive firms (KIFs) have been the subject of growing interest from researchers. However, investigations into the comparative experiences of men and women in KIFs remain sparse, and little is known about women's participation in the processes of innovation and knowledge exchange and combination that are core features of KIFs. We report on the findings of a study in the UK and Ireland involving 498 male and female knowledge workers in KIFs. Despite equal levels of qualification and experience, women are more likely to be in lower status and more insecure jobs. They also predominantly occupy roles featuring less variety and autonomy than men and, despite comparable levels of knowledge exchange and combination, are less likely to be in a position to translate this into the innovative work behaviours necessary for career advancement. Our findings suggest that women's experiences of and participation in knowledge processes within KIFs differ fundamentally from men's.
\end{abstract}

Key Words: gender equality, knowledge work, knowledge-intensive firms, pharmaceutical industry, ICT industry. 


\section{Knowledge Work: Gender-Blind or Gender-Biased?}

\section{Introduction}

Knowledge-intensive firms (KIFs) have been defined as: 'organisations within a knowledge economy that employ highly skilled individuals and therefore create market value through the application of knowledge to novel, complex client demands' (Swart and Kinnie, 2003, p. 62). Work within KIFs has been characterised as dynamic, autonomous and uncertain (Cordata, 1998; Frenkel et al., 1999; Kubo and Saka, 2002), reliant on the willing contribution of highly skilled and well-educated knowledge workers who exchange and combine knowledge and innovate in order to generate new ideas and capabilities (Alvesson, 2004; Nonaka and Takeuchi, 1995). Such firms can be viewed as distributed knowledge systems (Tsoukas, 1996), distinct from labour or capital intensive firms (Lowendahl, 1997), although the ambiguous, sometimes contradictory and fluid status of KIFs has led Karreman et al (2002: 71) to describe the term simply as a 'vague but meaningful category'. Nevertheless, the centrality of KIFs to economic growth and prosperity has been widely acknowledged.

Considerable research attention has focused on KIFs and knowledge work (Alvesson, 2004; Kang and Snell, 2009; McGrath, 2005; Starbuck, 1992). However, commentators concerned with understanding women's employment have criticised this body of work for being gender-neutral, or even gender-blind (Alvesson, 1998; Lauring and Selmer, 2011; Styhre et al., 2001). Some have pointed to the significant disadvantage experienced by women, for example, in terms of job role, career expectations, and salary (Guerrier et al., 2009; Moore et al., 2008), suggesting that KIFs, rather than creating the new opportunities for women heralded by the 'utopian' early literature (Toffler, 1981; Eaton, 1999; Walby, 2011), have instead simply redefined existing gender inequalities (Greco, 2005; Stanworth, 2000; Wajcman, 2004; Woodfield, 2002).

Despite advances in the field, our knowledge of women's experiences within KIFs remains generally limited to the two extremes of national-level statistics, and micro-level case studies (Duberley and Cohen, 2010; Guerrier et al., 2009). Quantitative comparisons of women's and men's subjective experiences are scarce (cf Baldry et al, 2007). Even less is known about how men and women knowledge workers compare in terms of their participation in the core processes central to the activities of KIFs, such as knowledge exchange and combination and innovation (cf Lauring and Selmer, 2011), the successful accomplishment of which has been linked with career advancement (Styhre et al., 2001). In this paper, we address these gaps in knowledge by focusing on two main questions. First, how do men's and women's subjective experiences as knowledge workers compare and, second, how do men and women knowledge workers participate in the core knowledge creation, exchange and combination processes which are central to innovation in KIFs?

The paper is structured as follows. First, we examine the relevant literature concerning the representation of women in the knowledge economy, and women's participation in knowledge processes within KIFs. We draw a set of hypotheses from this literature, and then explain the methodology we adopted to test them. After presenting our findings, we then discuss the wider implications of our study. 


\section{Women in KIFs}

Macro-level studies show that women are under-represented in many KIFs, comprising between $14 \%$ and $30 \%$ of the ICT labour force, where numbers are declining (Duberley and Cohen, 2010; Moore et al., 2008; Rosenbloom et al., 2008); 25-35\% of the science workforce (Benney, 2006); and $26 \%$ of university scientists and students (Rhoten and Pfirman, 2006). In addition, within these sectors women tend to be crowded into low-status, low-skill and often non-permanent peripheral occupations with few developmental opportunities, and to earn substantially less than men (Cross, 2009; Glover and Guerrier, 2010; Jubas and Butterwick, 2008; Kelan, 2007; Reid, 1998; Tharenou, 2005; Walby, 2011), despite statistics showing they possess comparable or higher levels of education and qualification (Bolton and Muzio, 2008; Jubas and Butterwick, 2008; Styhre et al., 2001) and the existence of equal opportunities legislation (d'Mello, 2006; Fisher, 2010; Stanworth, 2000). However, it has been found that women are somewhat more likely to be found in the higher level occupational groupings within KIFs than within the economy as a whole (Turner and McMahon, 2008; Walby, 2011).

Micro-level qualitative studies have attributed women's disadvantaged position in KIFs to multifactorial normative and structural influences (Alvesson, 1998; Jha and Welch, 2010). The prevalance of long working hours can render some jobs, normally career-track roles, unappealing to women, who then either experience substantial home/work role conflict or crowd into non-managerial enclaves and part-time jobs to achieve a desirable work-life balance (Chasserio and Legault, 2010; Crompton and Lyonette, 2006; Griffiths et al., 2007; Guerrier et al., 2009). Notions of 'skill', 'gender' and 'technology' may be co-produced through complex 'daily micro-level work practices' (Gray et al., 2007 , p. 144), yielding occupational routes up and through the firm that separately define men's (mainstream) roles and women's (peripheral) roles, whereby men are also more likely to have access to career-advancing training and development opportunities (Broadridge, 1998; Snyder and Green, 2008; Wajcman, 1991; 2007; Wood, 2008). Women's under-representation at more senior levels means they may also lack access to relevant networks and female mentors (Jha and Welch, 2010; McGuire, 2000). These factors combine to create what Duberley and Cohen (2010; p. 195) refer to as 'cumulative disadvantage' for women seeking to advance their careers, and challenge the assertion that technology acts as a leveller between the sexes in KIFs.

Accordingly, this evidence gives rise to a first set of hypotheses:

Hypothesis 1: Women knowledge workers will (a) work significantly fewer hours than men, (b) be significantly more negative about their work-life balance than men, and (c) experience significantly lower levels of job security than men.

Hypothesis 2: Women knowledge workers will experience significantly inferior (a) training and (b) career development opportunities compared with men.

Within knowledge-intensive firms, the central activity is the creation, deployment and management of knowledge to innovate and solve complex problems (Drucker, 1979; Frenkel et al., 1995). Whilst acknowledging its contested nature (Alvesson and Karreman, 2001), Benson and Brown (2007) argue that knowledge work has three core attributes: variety, the degree of reciprocal interdependence with other tasks, and autonomy. However, there have been very few prior quantitative studies comparing men's and women's participation in the production of knowledge, so we have little 
understanding of whether or how men and women differ in this regard (Lauring and Selmer, 2011; Styhre et al., 2001). The fact that qualitative studies have suggested women are clustered into subordinate work within KIFs would make it likely that more men than women undertake knowledge work in these settings. Knowledge work, which is perceived to enjoy higher status and power, may acquire association with notions of masculinity, whilst lower status, service-oriented roles acquire association with notions of femininity (Evans, 1994; Griffiths et al., 2007; Kelan, 2008). This has been supported in research showing that managers, HR professionals and women knowledge workers alike tended to adopt unquestioned assumptions about women's subordinated and marginalised work roles (Crump et al., 2007; Guerrier et al., 2009). Thus, we explore the degree to which women and men engage in knowledge work and hypothesise that:

Hypothesis 3: Women's jobs will feature significantly (a) less job variety, (b) lower levels of job autonomy, and (c) lower levels of task interdependence than men's in KIFs.

The core activities of KIFs are innovation and knowledge exchange and combination (Alavi and Leidner, 2001; Nahapiet and Ghoshal, 1998; Powell, 1998). Knowledge exchange and combination comprise anticipated value, learning and combination capability which Collins and Smith (2006) argue arise from a climate of trust and co-operation based on shared codes and language. However, the qualitative literature on women's work experiences would suggest that women's access to these shared codes may be structurally restricted compared with men's, due to such factors as the presence of lower numbers of women in the upper echelons and impoverished intra-firm networks (Crump et al., 2007; Durbin, 2011; Rhoten and Pfirman, 2006). Nonaka (1994) has argued that knowledge is created through processes of iteration between the explicit and codifiable, and the tacit and personal (Polanyi, 1966). Styhre et al. (2001, p.66) note that knowledge is also 'situational, embedded in social practices and world views', giving rise to multiple constructions of knowledge and knowledge management and, in particular, a distinction between 'legitimate' (male) knowledge, and 'peripheral' (female) knowledge); Lauring and Selmer's (2011) data show that gender diversity within groups can even impact negatively on processes of knowledge creation and sharing. Knowledge, whether tacit or explicit, should therefore be regarded not as a neutral construct, but as embedded in wider processes of gendering (Haraway, 1997). Thus, we could conjecture that women are less likely than men to have the opportunity to participate in knowledge exchange and combination processes.

Research on gender and innovation, although even more sparse (Ljunggren et al., 2010), has suggested that women are also more likely than men to be excluded from opportunities to participate in social exchanges oriented around innovation (Crowden, 2003). Innovation has, to some degree, been socially constructed as a masculine attribute associated with male-dominated industries (D'Mello, 2006; Maier, 1999). Equally, if women are clustered into more routinised roles within KIFs (Panteli et al., 1999), then they are likely to miss out on opportunities to innovate (Argote et al., 2003; Gray and James, 2007; Strohmeyer and Tonoyan, 2005), particularly since, as Finegold and Frenkel (2006) argue, in KIFs only a small group of people tend to be the primary drivers of value-creation. Additionally, as we have seen above, if women knowledge workers' qualifications and experience are comparable to those of men, but they are likely over-represented in peripheral roles that do not enable knowledge exchange and combination or innovation, then it can be conjectured that their levels of job-ability fit are likely to be lower than men's. These points give rise to our final set of hypotheses: 
Hypothesis 4: Women will display significantly lower levels of (a) ability-job fit, (b) knowledge exchange and combination activity, and (c) innovative work behaviour than male knowledge workers.

\section{Methods}

This study forms part of a wider research programme focusing on KIFs in the UK and Ireland. In order to investigate men's and women's perceptions and experiences of work in KIFs, survey data were gathered from individual employees.

\section{Settings and participants}

The research was undertaken across 14 firms in the pharmaceutical and ICT sectors in the UK and Ireland during 2009-10. Although definitions of knowledge-intensive firms and sectors are hotly debated and have become more fluid and encompassing, pharmaceuticals and ICT are typically identified as important 'knowledge economy' sectors employing large numbers of knowledge workers whether measured by qualification levels or skills usage (Brinkley 2008). In accessing these firms, we used a convenience sampling approach. We distributed a total of 1616 on-line surveys, of which 667 usable responses were returned, a response rate of $43 \%$. Consistent with prior studies of knowledge workers (Alvesson, 2001; Choi and Varney, 1995; Janz et al., 1997; Marks and Scholarios, 2007), we included in our analysis those respondents who held at least a primary degree and who were employed in technical and professional, as opposed to administrative roles. We therefore excluded 169 respondents who did not meet these criteria. Of the remaining 498 respondents in our sample, 328 were from the pharmaceutical sector and 170 were from the ICT sector. Respondents were employed in firms which varied in size from small indigenous employers through to large multinationals. In small firms, almost all employees participated. In larger firms we focused on particular departments/units selected to be as closely matched as possible with comparator units.

The number of responses varied from 10 to 131 in each firm, and response rates ranged from $19 \%$ in larger firms to $98 \%$ in some smaller firms. Within each firm, we checked for non-response bias by exploring differences according to key variables (e.g. gender, tenure and education) and for early versus late respondents, as it has been suggested that late respondents are similar to nonrespondents (Armstrong and Overton, 1977). This is known as a time trend extrapolation test. We found no significant differences. We also checked the profile of respondents against that of the employee profile provided by each firm and found them to be representative. Despite this, the convenience sampling strategy and the variety of firms represented may limit the generalisability of our findings. We therefore controlled for a number of additional variables in the analysis.

\section{Measures}

(a) Background characteristics. Variables relating to gender, education, job type and level, and level of annual earnings were measured using single items. Gender was coded as 1 for male and 0 for female. Education was coded as ranging from (1) no formal educational qualifications to (8) PhD.

(b) Hours of work, work-life balance and job security. Respondents were asked to indicate the average number of hours worked per week. Work-life balance was captured by a single item: 'I am satisfied with the balance that I have between my work and my life outside work'. Job security was 
measured using a single item measure which states 'I feel that my job is secure'. The scales for both work-life balance and job security ranged from strongly disagree (1) to strongly agree (5).

(c) Training and career opportunities. Training opportunities were measured using two items adapted from Collins and Smith (2006), for example, 'I am encouraged to enhance my skills through ongoing training and development in a broad range of areas'. The career opportunities measure comprised three items, for example, 'I feel I have all the opportunities I need to get promoted'. Scores for both ranged from strongly disagree (1) to strongly agree (5). We examined the structure of the items by carrying out an exploratory factor analysis using principal components (varimax rotation). The analysis yielded a single factor, but as we were interested in exploring each variable separately, we extracted two factors. This analysis clearly identified the items relating to training and career opportunities separately, and each item had an acceptable factor loading (>.5). The reliability coefficients for the training and career opportunities scales were .83 and .69 respectively.

(d) Knowledge work characteristics. We measured knowledge work characteristics using the variables adopted by Benson and Brown (2007). These were: job variety (Price and Mueller, 1981), job autonomy (Tetrick and LaRocco, 1987), and task interdependence (Kanungo, 1982). The variety and autonomy scales each contained three items, while the task interdependence scale contained four items. Sample items included: 'I have the opportunity to do a number of things in my job' (variety), 'I have a lot of input in deciding what tasks or parts of tasks I will do' (autonomy), and 'my job cannot be done unless other sections do their work' (task interdependence). Scores for these items ranged from strongly disagree (1) to strongly agree (5). The Cronbach's alpha coefficient for these scales was: job variety (.76), autonomy (.68), and task interdependence (.73).

(e) Perceived ability-job fit. Abdel-Halim's (1981) five item scale was used to measure perceived ability-job fit. Responses ranged from strongly disagree (1) to strongly agree (5). A sample item was 'I feel that my work utilises my full abilities' and 'my job gives me the chance to do the things I do best'. The reliability coefficient for the scale was .75 .

(f) Knowledge exchange and combination. This measure was adopted from Collins and Smith (2006) and contained eight items, for example, 'my co-workers and I see benefits from exchanging and combining ideas with one another' and 'I am willing to combine and exchange ideas with my coworkers'. Response options ranged from (1) strongly disagree to (5) strongly agree. The Cronbach's alpha for the scale was .87 .

(g) Innovative work behaviour. Janssen's (2000) measure of innovative work behaviour was used. It contained nine items relating to the generation of ideas, gaining support for ideas, and idea implementation. Respondents indicated the frequency with which they engaged in behaviours along a five-point scale ranging from 'never' (1) to 'always' (5). Items included 'generating original solutions for problems', 'transforming innovative ideas into useful applications', and 'generating original solutions for problems. The alpha coefficient for the scale was .93.

\section{Analysis}

Descriptive analysis was performed to calculate means and standard deviations for the full sample, as well as for gender. We first tested for gender differences in education, earnings, and level in the firm using cross-tabulations, chi-squares and analysis of the adjusted residuals. To test the first set 
of hypotheses, we examined gender differences using t-tests across the measures of working hours, work-life balance and job security. We used hierarchical regressions to test the remaining hypotheses, which enabled us to control for other potentially important variables. The control variables included in the regression analysis were country, sector, education, job level, and firm size. Country was coded as 1 for UK and 0 for Ireland, and sector was coded as 1 for pharmaceutical and 0 for ICT. We controlled for education in the same way as Mom et al. (2009) using two dummy variables: those with a master's degree or higher (1) and those with a primary degree (0). Job level was coded as 1 for manager and 0 for non-manager. Finally, firm size was coded as $(1)<50$ employees, (2) 50-250 employees, and (3) > 250 employees. We controlled for size by including respondents from firms employing less than 50 employees, and respondents from firms employing 250 or more employees.

\section{Findings}

Descriptive statistics for the demographic variables according to gender are presented in Table 1. INSERT TABLE 1 HERE

We found no significant gender differences regarding category of knowledge worker (professional versus technical), nor in levels of education between males and females. We can therefore conclude that the population of this study is similar in terms of level of education and type of work conducted.

From Table 1, we can see that women were significantly over-represented in the lower and middle category of earnings and significantly under-represented in the higher earnings category (Chisquare $=35.72, p<.01$ ), lending support to Blackburn et al's (2001) findings on the gender pay gap. We also found that women were less represented at top/senior management levels in these firms and instead were were more likely to occupy roles as front line managers (Chi-square $=14.46, p<$ $.01)$.

The means and standard deviations for the job-related variables are presented in Table 2.

\section{INSERT TABLE 2 HERE}

A t-test found that, on average, females worked significantly fewer hours per week than males ( $\mathrm{t}=$ $5.27, \mathrm{p}<.001)$. This supports hypothesis $1 \mathrm{a}$. Hypothesis $1 \mathrm{~b}$, which tested whether women's experiences of work-life balance would be significantly more negative than men's, was not supported ( $t=.002, p>.05)$. Regarding job security, we found that women experienced significantly less job security than men $(t=-1.99, p<.05)$. This supports hypothesis $1 c$.

To test the remaining hypotheses, we used both a series of $\mathrm{t}$-tests followed by regression analyses to allow us to control for differences according to country, sector, education and job level. First, we report the findings of the t-tests.

The t-tests revealed that women experienced better opportunities for workplace training (hypothesis $2 \mathrm{a} ; \mathrm{t}=2.50, \mathrm{p}<.05$ ), but had poorer perceptions of their career prospects than men (hypothesis $2 b ; t=-3.12, p<.01$ ). These findings provide support for hypothesis $2 b$, but are contrary to what was predicted in hypothesis $2 \mathrm{a}$. 
We used the t-tests to compare women's and men's experiences according to three key characteristics of knowledge work (Benson and Brown, 2007). These showed that women experienced lower levels of variety in their jobs $(t=-2.20, p<.05)$ and had significantly more negative perceptions about their level of autonomy at work $(t=-2.84, p<.01)$. This supports hypotheses $3 \mathrm{a}$ and $3 \mathrm{~b}$. However, contrary to hypothesis $3 \mathrm{c}$, women did not experience significantly lower levels of task interdependence compared to men $(t=-.648, p=>.05)$. The $t$-tests also showed that perceptions of ability-job fit were not significantly lower for women than for men (hypothesis $4 a ; t=-1.54, p=>.05$ ). In addition, the level of knowledge exchange and combination undertaken by men and women did not significantly differ (hypothesis $4 b ; t=-.257, p=>.05$ ). However, the tests revealed that women were significantly less likely to engage in innovative work behaviours compared with men $(t=-2.10, p<.05)$. This supports hypothesis $4 c$.

Gender differences across each of the work-related variables were investigated further using correlation and hierarchical regression analysis. The correlations are presented in Table 3.

\section{INSERT TABLE 3 HERE}

The correlations show significant relationships between gender and a number of work-related variables, namely: training and career opportunities, job variety, job autonomy, and innovative work behaviour. In the regression analysis, we set out to explore whether patterns of relationships reported here remained, even after controlling for a variety of background variables. We therefore controlled for country, sector, education, job level, and firm size in the first step, and then entered gender in the second step. Table 4 shows the standardised betas at the final step.

\section{INSERT TABLE 4 HERE}

The results show there were no significant differences regarding access to work-related training opportunities between men and women $(\beta=-.07, p=>.05)$ when controlling for these background variables. Thus, hypothesis $2 \mathrm{a}$ is not supported. Regarding career prospects, the regression shows that women had more negative views about their opportunities for career development compared with men, even when these other variables are controlled $(\beta=.09, p<.05)$. Thus, hypothesis $2 b$ is supported. The findings show that females were significantly less likely to perceive themselves as engaged in knowledge work as measured by job variety $(\beta=.13, p=<.01)$ and job autonomy ( $\beta=$ $.13, p<.01)$, but not task interdependence $(\beta=.05, p>.05)$. These findings lend further support to hypotheses $3 a$ and $3 b$ (though not $3 c$ ), when controlling for these background variables. The analysis found no significant gender differences regarding perceptions of ability-job fit ( $\beta=.08, p$ $>.05$ ) and knowledge exchange and combination $(\beta=.02, p>.05)$. Thus, hypotheses $4 \mathrm{a}$ and $4 \mathrm{~b}$ are not supported. Finally, the findings show that women were significantly less likely to engage in innovative work behaviours when compared to men $(\beta=.13, p<.01)$. This further supports hypothesis 4c.

\section{Discussion and Conclusions}

Our survey of male and female knowledge workers in the UK and Ireland focussed on the software and pharmaceutical sectors. We found that although men and women had comparable levels of education, women earned significantly less than men and were less well represented in higher grade roles. These findings reflect those reported in other studies exploring both education (Fisher, 2010; 
Griffiths et al., 2007; Walby, 2011) and earnings (Blackburn et al., 2001; Glover and Guerrier, 2010; Griffiths et al., 2007), but also suggest that Blackburn and Jarman's (2006) finding of convergence between men's and women's overall occupational distribution has not been reflected within the knowledge intensive sectors.

A number of our hypotheses concerning the experience of work were supported. In line with previous studies, we found that women worked shorter hours than men (Chasserio and Legault, 2010; Griffiths et al., 2007; Guerrier et al., 2009), and were as satisfied as their male colleagues with their work-life balance. However, women experienced significantly lower levels of job security compared with men, underlining the relatively more precarious and disadvantaged situation of women knowledge workers. These findings lend further support to the trends reflected in other studies focusing on women's work experiences in KIFs (Duberley and Cohen, 2010; Griffiths et al., 2007; Guerrier et al., 2009; Styhre et al., 2001), and extends them by incorporating a comparison of both men and women employed within the same firms.

Our second set of hypotheses concerned careers. We found that women's perceptions of career prospects were significantly more negative than men's, even when controlling for other background variables. Again, this suggests that women become clustered into lower-status roles outside the organisational hierarchy that limit their career development opportunities (Duberley and Cohen, 2010; Fisher, 2010). However, contrary to prediction (Panteli et al., 1999), we found that women's perceptions of their access to training and development at work were not significantly more negative than men's. Possible explanations for this include a lower level of expectation on the part of women; women choosing to self-fund and source training (Jubas and Butterwick, 2008); or simply that women had in fact received more training than men, reflecting some national trends (ONS, 2002). Possibly, given women's over-representation in lower-status roles, it may be that women are deepening their specialist skills through narrowly based training rather than acquiring the generalist skills that would support their longer term careers (Walby, 2011). Further research that explores this issue in more depth is warranted.

Our next set of hypotheses concerned women's participation in knowledge work within KIFs. When controlling for background variables, we found that women reported significantly lower levels of job variety and job autonomy, but comparable levels of task interdependence compared with men. This runs somewhat counter to the findings of Baldry et al. (2007) whose data from a survey of men and women working in IT revealed comparable levels of cognitive task complexity, although this comparison should be treated with some caution due to the small sample size and different construct measurement.

While similar levels of education are reported by men and women, we found no difference between the genders in perceived levels of ability-job fit, even taking into account differences in job content. As expected, women also reported significantly lower levels of IWB even when taking job level into account, but, contrary to expectations and contrary to the findings of Durbin (2011), there were no differences in the level of reported knowledge exchange and combination.

There are various possible explanations for this. It may be the case that women's overrepresentation in lower level and relatively insecure roles means that they lack the opportunity to translate their knowledge exchange and combination skills into IWBs, or into experiences that are likely to enhance their career capital (Duberley and Cohen, 2010). More senior role incumbents may 
have more access to opportunities to develop generalist skills relevant for the discovery and application of new knowledge (Shane, 2000; Taylor and Greve, 2006), an opportunity possibly less available to women knowledge workers. Equally, the findings may reflect structural differences between men's and women's networks highlighted elsewhere as detrimental to women's access to resources and information (Crump et al., 2007; Durbin, 2011; Gray et al., 2007; Jha and Welch, 2010), or alternatively they may lack the confidence to display IWBs. This is likely to create a negative cycle whereby lack of innovation further exacerbates women's disadvantaged trajectory through creating career deficits (Duberley and Cohen, 2010). Future research exploring these processes further would be welcome.

Our findings point to the importance of a number of relevant background variables, which help to further explain these work-related outcomes. In particular, our analysis reveals the important role of education in facilitating opportunities for job variety, ability-job fit and innovative work behaviours in KIFs. This suggests that access to higher education can enhance opportunities to engage in both relevant and meaningful work for employees in KIFs. We also identified country differences which suggest that training and career opportunities are viewed less favourably in the UK compared to Ireland. Interestingly, training opportunities were viewed more favourably in larger firms, while career opportunities were viewed more favourably in smaller firms. We found evidence for higher levels of job variety in smaller firms reflecting possible differences between the agility and responsiveness of small organic organisations as compared with large bureaucracies. Our findings also suggest that IWBs were more evident in pharmaceutical rather than in ICT firms. Despite this, however, our research suggests that significant gender differences persist across a number of these outcomes, regardless of setting.

Although our study has been able to shed light on some important issues concerning gender and $\mathrm{KIFs}$, a number of limitations should be highlighted. First, more information concerning normative factors influencing male and female work experiences would have enabled us to examine in more detail the interaction between these and structural issues. Further research that explores this in more depth would be welcome. Second, our study involved respondents from more than one sector and country, and from firms of various sizes. As the primary unit of our analysis is the knowledge worker, we made the assumption that the experiences of similar individuals in the same organisation, and between similar individuals across different organisations, would be comparable. This approach was supported by evidence which suggests that different task environments are institutionalised and that individuals working in different sectors and industries can perceive their environments in similar ways (e.g. Daniels, Johnson and de Cherantony, 2002). However, further research examining whether, how and under what circumstances perceived experiences may vary between KIFs is welcome. The gender profile in the ICT sector was quite uneven compared to the pharmaceutical sector, which precluded a gender breakdown of the sample by sector, even though the proportion of females in the ICT sector in our sample (13.5\%) is in line with industry estimates and other studies (Baldry et al., 2007).

We regard Ireland and the UK as operating in broadly similar contexts. However, we could have included cultural level difference variables to examine these issues more closely. While it is suggested that geographical proximity may be a driver of cognitive convergence (e.g. Daniels et al., 2002), and may lead to mimetic isomorphism in management practices (Goodstein, 1994), there is also evidence to suggest that human resource management practices and gendering processes differ 
across national contexts (e.g. Crompton and Lyonette, 2006; Mayrhofer, Morley and Brewster, 2004). We would therefore welcome further research that examines these issues across an even wider range of firms and national settings, and using larger datasets with higher response rates.

Despite these limitations, our study is the first quantitative comparison of men's and women's participation in knowledge exchange and combination and IWB within KIFs in two different sectors and in two countries. We have made two main contributions. First, we have made an empirical contribution to the hitherto very sparse literature comparing men's and women's work experiences in knowledge-intensive firms. We have shed additional light on existing findings from micro-level case studies and macro-level industry data that suggest women are disadvantaged in KIFs compared with men in terms of job, role, career trajectory and working conditions.

Second, we have made a theoretical and empirical contribution to the field by bringing together the hitherto disconnected literatures relating to knowledge exchange and combination, IWB and gender. We have shown that the knowledge process itself is gendered (Styhre et al., 2001), and suggest that although women and men may exchange and combine knowledge to the same degree, women's segregation into lower-status and more routinised roles means that they are not able to translate this into innovative work behaviours, thus further depleting their career capital (Duberley and Cohen, 2010), and fostering a cycle of disadvantage for women in the knowledge economy. 


\section{References}

Abdel-Halim, A. A. (1981) 'A re-examination of ability as a moderator of role perceptionssatisfaction relationship'. Personnel Psychology, 34, 549-562.

Alavi, M. and Leidner, D. (2001) 'Knowledge Management and Knowledge Management Systems: Conceptual Foundations and Research Issues'. MIS Quarterly, 25(1): 107-36.

Alvesson, M. (1998) 'Gender Relations and Identity at Work: A Case Study of Masculinities and Femininities in an Advertising Agency', Human Relations, 51(8): 969-1005.

Alvesson, M. (2001) 'Knowledge work: ambiguity, image and identity', Human Relations, 54(7): 863886.

Alvesson, M. (2004) Knowledge Work and Knowledge-intensive Firms. Oxford: Oxford University Press.

Alvesson, M. and Karreman, D. (2001) 'Odd Couple: Making Sense of the Curious Concept of Knowledge Management', Journal of Management Studies, 38(7): 995-1018.

Argote, L., McEvily, B. and Reagans, R. (2003) 'Managing Knowledge in Organizations: An Integrative Framework and Review of Emerging Themes', Management Science, 49: 571-82.

Armstrong, S. J. and Overton, T. S. (1977) 'Estimating non-response bias in mail surveys', Journal of Marketing Research, 14(3): 396-402.

Baldry, C., Bain, P., Taylor, P., Hyman, J., Scholarios, D., Marks, A., Watson, A., Gilbert, K., Gall G. and Bunzel, D. (2007) The Meaning of Work in the New Economy. Basingstoke: Palgrave.

Benney, A. (2006) 'Wanted: Women Scientists', OECD Observer October (257): 23.

Benson, J. and Brown, M. (2007) 'Knowledge Workers: What Keeps them Committed; What Turns them Away', Work, Employment and Society 2(1): 121-41.

Blackburn, R., Brooks, B. and Jarman, J. (2001) 'The Vertical Dimension of Occupational Segregation', Work, Employment and Society, 15(3): 511-538.

Blackburn, R. and Jarman, J. (2006) 'Gendered Occupations: Exploring the Relationship betwen Gender Segregation and Inequality', International Sociology, 21(2): 289-315.

Brinkley, I. (2006) Defining the Knowledge Economy, London: The Work Foundation.Brinkley, I. (2008), The Knowledge Economy? The Economic Life of Nations, London: The Work Foundation.

Broadridge, A. (1998) 'Barriers in the Career Progression of Retail Managers', International Review of Retail, 8(1): 53-78.

Chasserio, S. and Legault, M. (2010 in press) 'Discretionary Power of Project Managers in Knowledge-Intensive Firms and Gender Issues', Canadian Journal of Administrative Sciences.

Choi, T.Y. and Varney, G.H. (1995) 'Rethinking the knowledge workers: where have all the workers gone?', Organizational Development Journal, 13, 41-50. 
Collins, C. and Smith, K. (2006) 'Knowledge Exchange and Combination: The Role of Human Resource Practices in the Performance of High-Technology Firms'. Academy of Management Journal, 49(3): 544-60.

Cordata, J. (1998) Rise of the Knowledge Worker. Boston: Butterworth-Heinemann.

Crompton, R. and Lyonette, C. (2006) 'Some Issues in Cross-National Comparative Research Methods: A Comparison of Attitudes to Promotion and Women's Employment in Britain and Portugal', Work, Employment and Society 20(2): 403-414.

Cross, C. (2009) 'Barriers to the Executive Suite: Evidence from Ireland', Leadership and Organization Development Journal, 31(2): 104-119.

Crowden, N. (2003) Examining Gender Biases in Studies of Innovation. Unpublished MA Thesis, Simon Fraser University, Canada.

Crump, B., Logan, K. And Mcllroy, A. (2007) 'Does Gender Still Matter? A Study of the Views of Women in the ICT Industry in New Zealand', Gender, Work and Organization 14(4): 349-370.

D'Mello, M. (2006) 'Gendered Selves and Identities of Information Technology Professionals in Global Software Organizations in India', Information Technology for Development, 12(2): 131-158.

Daniels, K., Johnson, G., and de Cernatony, J. (2002) 'Task and institutional influences on managers' mental models of competition', Organization Studies, 23(1): 31-62.

Drentea, P. (1998) 'Consequences of Women's Formal and Informal Job Search Methods for Employment in Female-Dominated Jobs', Gender and Society, 12(3): 321-38.

Drucker, P. (1979) 'Managing the Knowledge Worker', Modern Office Procedures 24: 12-16.

Duberley, J. and Cohen, L. (2010) 'Gendering Career Capital: An Investigation of Scientific Careers', Journal of Vocational Behavior 76: 187-97.

Durbin (2011) 'Creating Knowledge through Networks: A Gender Perspective', Gender, Work and Organisation 18(1): 90-112.

Eaton, S. (1999) 'Surprising Opportunities: Gender and the Structure of Work in Biotechnology Firms'. In C.C. Selby (Ed) Annals of New York Academy of Sciences, Vol 869.

Evans, M. (1994) The Women Question. London: Sage.

Finegold, D., and Frenkel, S. (2006) 'Managing People where People Really Matter: The Management of Human Resources in Biotech Companies', International Journal of Human Resource Management, 17(1): $1-24$

Fisher, J. (2010) 'Re-Inscribing Gender in New Modes of Medical Expertise: The InvestigatorCoordinator Relationship in the Clinical Trials Industry', Gender, Work and Organization 17(2): 150173. 
Frenkel, S., Korcyznski, M., Donohue, L., and Shire, K. (1995) 'Re-Constituting Work', Work, Employment and Society, 9(4): 773-96.

Frenkel, S., Korczynski, M., Shire, K. and Tam, M. (1999) On the Front Line. Ithaca: Cornell University Press.

Glover, J. and Guerrier, Y. (2010) 'Women in Hybrid Roles in IT Employment: A Return to 'Nimble Fingers'?' Journal of Technology Management and Innovation 5(1): 85-94.

Goodstein, J.D. (1994) 'Institutional pressures and strategic responsiveness: employer involvement in work-family issues', Academy of Management Journal, 37: 350-382.

Gray, M., Kurihara, T., Hommen, L. and Feldman, J. (2007) 'Networks of Exclusion: Job Segmentation and Social Networks in the Knowledge Economy', Equal Opportunities International 26(2): 144-61.

Gray, M. and James, A. (2007) 'Connecting Gender and Economic Competitiveness: Lessons from Cambridge's High Tech Regional Economy', Environment and Planning.

Greco, L. (2005) 'Knowledge-Intensive Organisations: Women's Promised Land? The Case of the Irish Software Companies', Irish Journal of Sociology, 14(1): 45-65.

Griffiths, M., Moore, K. and Richardson, H. (2007) 'Celebrating Heterogeneity: A Survey of Female ICT Professionals in England', Information, Communication and Society, 10(3): 338-57.

Guerrier, Y., Evans, C., Glover, J. and Wilson, C. (2009) 'Technical, but not very ... Constructing Gendered Identities in IT-Related Employment' Work, Employment and Society, 23(3): 494-511.

Haraway, D. (1991) Semians, Cyborgs and Women: The Reinvention of Nature. London: Free Association Books.

Haraway, D. (1997) Modest_Witness@Second_Millennium.FemaleManC_Meets_OncoMouse ${ }^{T M}$. London: Routledge.

Janssen, O. (2000) 'Job demands, perceptions of effort-reward fairness and innovative work behavior', Journal of Occupational and Organizational Psychology, 73: 287-302.

Janz, B.D., Colquitt, J.A., and Noe, R.A. (1997) 'Knowledge worker team effectiveness: the role of autonomy, interdependence, team development, and contextual support variables', Personnel Psychology, 50, 877-904.

Jha, Y. and Welch, E. (2010) 'Relational Mechanisms Governing Multifaceted Collaborative Behavior of Academic Scientists in Six Fields of Science and Engineering', Research Policy, 39: 1174-1184.

Jubas, K. and Butterwick, S. (2008) 'Hard/Soft, Formal/Informal, Work/Learning: Tenuous/Persistent Binaries in the Knowledge-Based Society', Journal of Workplace Learning, 20(7/8): 514-525.

Kang, S. and Snell, S. (2009) 'Intellectual Capital Architectures and Ambidextrous Learning: A Framework for Human Resource Management', Journal of Management Studies, 46(1): 65-91. 
Kanungo, R. (1982), 'Measurement of Job and Work Involvement', Journal of Applied Psychology, 67 (3): 341-351.

Karreman, D., Sveningsson, S. and Alvesson, M. (2002) 'The Return of the Machine Bureaucracy?', International Studies of Management and Organization 32(2): 70-92.

Kelan, E. (2008) 'Emotions in a Rational Profession: the Gendering of Skills in ICT Work', Gender, Work and Organization 15(1) 49-71.

Kogut, B. and Zander, U. (1992) 'Knowledge of the Firm, Combinative Capabilities and the Replication of Technology', Organization Science, 3(3): 383-97.

Kubo, I. and Saka, A. (2002) 'An Inquiry into the Motivations of Knowledge Workers in the Japanese Financial Industry', Journal of Knowledge Management,6(3): 262-71.

Lauring, J. and Selmer, J. (2011 in press) 'Knowledge Sharing in Diverse Organisations', Human Resource Management Journal.

Ljunggren, E., Alsos, G., Amble, N., Ervik, R., Kvindal, T. and Wiik, R. (2010) Gender and Innovation: Learning from Regional VRI- Projects. Nordland Research Institute, Norway, Report No. 978-82-7321591-8.

Lowendahl., B. (1997) Strategic Management of Professional Service Firms. Copenhagen: Handelshojskolens Forlag.

Maier, M. (1999) 'On the Gendered Substructure of Organisation: Dimensions and Dilemmas of Corporate Masculinity'. In Powell, G. (Ed) Handbook for Gender and Work, 69-95, New York: Sage.

Mayrhofer, W., Morley, M., and Brewster, C. (2004) 'Convergence, statis, or divergence?' In C. Brewster, W. Mayrhofer, and M. Morley (Eds). Human Resource Management in Europe: Evidence of convergence? (pp. 417-436). London: Elsevier/Butterworth-Heinemann.

Marks, A. and Scholarios, D. (2007) 'Revisiting technical workers: professional and organisational identities in the software industries', New Technology, Work and Employment, 22(2): 98-117.

McGuire, G. (2000) 'Gender, Race, Ethnicity and Networks: The Factors Affecting the Status of Employees' Network Members', Work and Occupations, 27(4): 500-23.

McGrath, P. (2005) 'Thinking differently about knowledge-intensive firms: Insights from early medieval monasticism' Organization 12(4): 549-566.

Moore, K., Griffiths, M., Richardson, H. and Adam, A. (2008) 'Gendered Futures? Women, the ICT Workplace and Stories of the Future', Gender, Work and Organization 15(5): 523-42.

Nahapiet, J. and Ghoshal, S. (1998) 'Social Capital, Intellectual Capital and the Organizational Advantage', Academy of Management Review. 23:242-266.

Nonaka, I. (1994) 'A Dynamic Theory of Organizational Knowledge Creation', Organization Science. 5(1): 14-37. 
Nonaka, I. and Takeuchi, H (1995) The Knowledge-Creating Company. Oxford: Oxford University Press.

ONS (2002) National Learning Targets: By Gender, Social Trends 32.

Panteli, A., Stack, J., Atkinson, M. and Ramsay, H. (1999) 'The Status of Women in the UK IT Industry: An Empirical Study', European Journal of Information Systems, 8(3): 170-82.

Polanyi, M. (1966). The Tacit Dimension. Doubleday, Garden City, NY.

Powell, W. (1998) 'Learning from Collaboration: Knowledge and Networks in the Biotechnology and Pharmaceutical Industries', California Management Review 40: 3228-240.

Price, J. and Mueller, C. (1981), Professional Turnover: The Case of Nurses. New York: SP Medical and Scientific.

Rhoten, D. and Pfirman, S. (2006) 'Women in Interdisciplinary Science: Exploring Preferences and Consequences', Research Policy, 36: 56-75.

Rosenbloom, J., Ash, R., Dupont, B. and Coder, L. (2008) 'Why are there so Few Women in Information Technology: Assessing the Role of Personality in Career Choices', Journal of Economic Psychology, 29: 543-54.

Shane, S. (2000) 'Prior Knowledge and the Discovery of Entrepreneurial Opportunities', Organization Science, 11(4): 448-469.

Snyder, K. and Green, A. (2008) 'Revising the Glass Escalator: The Case of Gender Segregation in a Female Dominated Occupation' Social Problems 55(2): 271-299.

Stanworth, C. (2000) 'Women and Work in the Information Age', Gender, Work and Organization 1 (7): 20-32.

Starbuck, W. (1992) 'Learning by Knowledge-Intensive Firms', Journal of Management Studies 3(4): 262-75.

Strohmeyer, R. and Tonoyan, V. (2005) 'Bridging the Gender Gap in Employment Growth: On the Role of Innovativeness and Occupational Segregation', International Journal of Entrepreneurship and Innovation, 6(4): 259-273.

Styhre, A., Ingelgård, A., and Roth, J. (2001) 'Gendering Knowledge: The Practices of Knowledge Management in the Pharmaceutical Industry', Knowledge and Process Management, 8(2): 65-74.

Swart, J. and Kinnie, N. (2003) 'Sharing Knowledge in Knowledge-Intensive Firms', Human Resource Management Journal 13(2): 60-75.

Taylor, A. and Greve, H. (2006) 'Superman or the Fantastic Four: Knowledge Combination and Experience in Innovative Teams', Academy of Management Journal, 49(4): 723-740. 
Tetrick, L. and LaRocco, J. (1987), 'Understanding, Prediction, and Control as Moderators of the Relationships between Perceived Stress, Satisfaction, and Psychological Well-being', Journal of Applied Psychology 72: 538-43.

Tharenou, P. (2005) 'Women's Advancement in Management', in Burke, R. and Mattis, M. (Eds) Supporting Women's Career Advancement: Challenges and Opportunities. Northampton, MA: Edward Elgar Publishing.

Toffler, A. (1981) The Third Wave. London: Pan Books.

Tsoukas, H. (1996) 'The Firm as Distributed Knowledge System: An Exploratory Study', Strategic Management Journal, 17: 11-25.

Turner, T. and McMahon, J. (2008) 'Women and Occupations in the Irish Economy: An Era of New Opportunities?' Administration 56(1): 111-131.

Wajcman, J. (1991) Feminism Confronts Technology. Cambridge: Polity Press.

Wajcman, J. (2004) Technofeminism. Cambridge: Polity Press.

Wajcman, J. (2007) 'From Women and Technology to Gendered Technoscience', Information, Communication and Society 10(3): 287-98.

Walby, S. (2011) 'Is the Knowledge Society Gendered?' Gender, Work and Organisation, 18(1): 1-29.

Wood, G. (2008) 'Gender Stereotypical Attitudes: Past, Present and Future Influences on Women's Career Advancement', Equal Opportunities International 27(7): 613-28.

Woodfield, R. (2002) 'Women and Information Systems Development: Not Just a Pretty (Inter)face?' Information, Technology and People 15(2): 119-38. 
Table 1 Distribution of the respondents by key demographic variables according to gender (\%)

\begin{tabular}{|l|c|c|}
\hline & $\begin{array}{c}\text { WOMEN } \\
(\%)\end{array}$ & $\begin{array}{c}\text { MEN } \\
(\%)\end{array}$ \\
\hline Gender & 34 & 66 \\
\hline Job Type & & \\
\hline Professional & 18.5 & 35.7 \\
Technical & 15.7 & 30.1 \\
\hline Level of Education & 18.3 & 34.5 \\
\hline Primary degree & 9.6 & 17.7 \\
Masters degree & 6.2 & 13.7 \\
PhD & & \\
\hline Level of Earnings & \\
\hline Up to $€ 40,000$ or $£ 29,999$ & $12.9(+)$ & 14.4 \\
€40,000 -55,000 or $£ 30,000-39,999$ & $18.6(+)$ & 16.2 \\
Over €55,000 or $£ 40,000$ & $6.9(-)$ & 30.9 \\
\hline Job Level** & & \\
Top/ Senior management & $4.1(-)$ & 15.1 \\
Middle management & 3.5 & 8.0 \\
Front-line management & $16.4(+)$ & 21.3 \\
Non-management & 10.4 & 21.3 \\
\hline
\end{tabular}

${ }^{*} \mathrm{p}<.05{ }^{* *} \mathrm{p}<.01 ;{ }^{* * *} \mathrm{p}<.001$

('+' indicates significantly higher proportions, and '-' significantly lower proportions) 
Table 2 Means and standard deviations for job-related variables by gender

\begin{tabular}{|l|c|c|c|}
\hline & $\begin{array}{c}\text { Females } \\
\mathrm{M}(\mathrm{SD})\end{array}$ & $\begin{array}{c}\text { Males } \\
\mathrm{M}(\mathrm{SD})\end{array}$ & $\begin{array}{c}\text { Overall sample } \\
\mathrm{M}(\mathrm{SD})\end{array}$ \\
\hline Working hours & $39.43(5.80)^{*}$ & $42.35(5.82)$ & $41.35(5.97)$ \\
\hline Work-life balance & $3.49(1.08)$ & $3.49(1.01)$ & $3.49(1.03)$ \\
\hline Job security & $3.02(1.06)^{*}$ & $3.23(1.08)$ & $3.16(1.08)$ \\
\hline Training opportunities & $3.43(.88)^{*}$ & $3.20(.99)$ & $3.28(.96)$ \\
\hline Career opportunities & $2.91(.87)^{* *}$ & $3.05(.82)$ & $2.96(.86)$ \\
\hline Job variety & $3.65(.75)^{*}$ & $3.79(.68)$ & $3.74(.71)$ \\
\hline Job autonomy & $3.39(.67)^{* *}$ & $3.57(.65)$ & $3.51(.66)$ \\
\hline Task interdependence & $3.88(.71)$ & $3.92(.71)$ & $3.91(.71)$ \\
\hline Ability-job fit & $3.76(.61)$ & $3.85(.58)$ & $3.82(.59)$ \\
\hline Knowledge exchange \& comb. & $3.95(.54)$ & $3.96(.50)$ & $3.96(.51)$ \\
\hline Innovative work behaviour & $3.23(.65)^{*}$ & $3.36(.67)$ & $3.32(.67)$ \\
\hline
\end{tabular}

$* \mathrm{p}<.05 ;{ }^{* *} \mathrm{p}<.01$; $^{* * *} \mathrm{p}<.001$ 
Table 3 Means, standard deviations, correlations and reliabilities

\begin{tabular}{|c|c|c|c|c|c|c|c|c|c|c|c|c|c|}
\hline Measures & M & SD & 1. & 2. & 3. & 4. & 5. & 6. & 7. & 8. & 9. & 10. & 11. \\
\hline 1. Innovative Work Behaviour & 3.32 & .67 & (.93) & & & & & & & & & & \\
\hline 2. Knowledge Exchange \& Combination & 3.96 & .51 & $.38 * * *$ & $(.87)$ & & & & & & & & & \\
\hline 3. Ability-Job Fit & 3.82 & .59 & $.37 * * *$ & $.41 * * *$ & $(.75)$ & & & & & & & & \\
\hline 4. Job Variety & 3.74 & .71 & $.38 * * *$ & $.37 * * *$ & $.53 * * *$ & $(.76)$ & & & & & & & \\
\hline 5. Job Autonomy & 3.51 & .66 & $.33 * * *$ & $.29 * * *$ & $.50 * * *$ & $.53 * * *$ & (.68) & & & & & & \\
\hline 6. Task Interdependence & 3.91 & .71 & $.16^{* * *}$ & $.18^{* * *}$ & $.17 * * *$ & $.09 * *$ & .01 & $(.723$ & & & & & \\
\hline 7. Training Opportunities & 3.28 & .96 & $.13^{* *}$ & $.32 * * *$ & $.39 * * *$ & $.32 * * *$ & $.25 * * *$ & $.09 *$ & $(.83)$ & & & & \\
\hline 8. Career Opportunities & 2.96 & .86 & $.22^{* * *}$ & $.34 * * *$ & $.43 * * *$ & $.41 * * *$ & $.32 * * *$ & $.18^{* * *}$ & $.52 * * *$ & $(.69)$ & & & \\
\hline 9. Education & 6.67 & .78 & $.17 * * *$ & .05 & .06 & .08 & .07 & .02 & -.02 & .01 & - & & \\
\hline 10. Level (Manager) & .68 & .46 & $.09 *$ & -.01 & -.01 & $.11^{*}$ & -.01 & $.12 * *$ & .02 & -.01 & -.02 & - & \\
\hline 11. Firm Size & 2.65 & .62 & .02 & .01 & -.02 & .03 & -.08 & .03 & $.17 * * *$ & -.06 & $.26 * * *$ & -.04 & - \\
\hline 12. Gender & .66 & .47 & $.09 *$ & .01 & .07 & $.10^{*}$ & $.13^{* *}$ & .03 & $.11^{*}$ & $.09 *$ & .02 & -.02 & $-.10^{*}$ \\
\hline
\end{tabular}

$* \mathrm{p}<.05 ;^{* *} \mathrm{p}<.01{ }^{* * *} \mathrm{p}<.001 . \mathrm{N}=498$. 
Table 4 Hierarchical regression of work related outcomes on gender (standardised betas)

\begin{tabular}{|c|c|c|c|c|c|c|c|c|}
\hline Variables & $\begin{array}{c}\text { Training } \\
\text { Opportunities }\end{array}$ & $\begin{array}{c}\text { Career } \\
\text { Opportunities }\end{array}$ & $\begin{array}{l}\text { Job } \\
\text { Variety }\end{array}$ & Autonomy & $\begin{array}{c}\text { Task } \\
\text { Interdependence }\end{array}$ & $\begin{array}{c}\text { Ability-Job } \\
\text { Fit }\end{array}$ & $\begin{array}{c}\text { Knowledge Exchange } \\
\text { \& Combination }\end{array}$ & $\begin{array}{l}\text { Innovative } \\
\text { Work Behaviour }\end{array}$ \\
\hline \multicolumn{9}{|l|}{ Block 1: Control variables } \\
\hline Country & $-.22 * * *$ & $-.14 *$ & -.02 & .08 & -.05 & -.07 & -.05 & -.01 \\
\hline Sector & -.02 & -.05 & .08 & .07 & .04 & .06 & .01 & $.19 * *$ \\
\hline Education (Masters/ PhD) & .02 & .08 & $.11^{*}$ & .04 &. .00 & $.10^{*}$ & .06 & $.17^{* * *}$ \\
\hline Level (Manager) & -.07 & -.06 & $.11^{*}$ & .02 & .10 & -.05 & -.02 & .06 \\
\hline Size (Small) & .05 & $.16^{* *}$ & $.17^{* *}$ & .07 & .07 & .05 & .07 & .06 \\
\hline Size (Large) & $.19 * *$ & .05 & .11 & -.08 & .07 & -.05 & .05 & -.07 \\
\hline Adj. $R^{2}$ & .06 & .02 & .04 & .01 & .01 & .00 & -.00 & .04 \\
\hline F-value & $6.01 * * *$ & $2.82 *$ & $4.54^{* * *}$ & 1.55 & 1.91 & 1.18 & .64 & $4.42 * * *$ \\
\hline \multicolumn{9}{|l|}{ Block 2: Gender } \\
\hline Gender & -.07 & $.09 *$ & $.13^{* *}$ & $.13^{* *}$ & .05 & .08 & .02 & $.14^{* *}$ \\
\hline Adj. $R^{2}$ & .06 & .03 & .05 & .02 & .01 & .01 & -.01 & .06 \\
\hline F-value & $5.46^{* * *}$ & $2.84^{* *}$ & $5.02 * * *$ & $2.34^{*}$ & 1.80 & 1.47 & .58 & $5.08 * * *$ \\
\hline$F$-value for change in $R^{2}$ & 2.07 & $2.99 *$ & $7.58^{* *}$ & $7.29 * *$ & 1.16 & 3.21 & .19 & $8.63^{* *}$ \\
\hline
\end{tabular}

